\title{
Commentary How does the estrogen receptor work?
} Jennifer M Gross and Douglas Yee

University of Minnesota Cancer Center, Department of Pharmacology, Minneapolis, Minnesota, USA

Correspondence: Douglas Yee, University of Minnesota Cancer Center, Department of Medicine and Pharmacology, MMC 806, 420 Delaware Street SE, Minneapolis, MN 55455, USA. Tel: +1 612626 8487; fax: +1 612626 4842; e-mail: yeexx006@umn.edu

Received: 17 December 2001

Revisions requested: 23 January 2002

Revisions received: 30 January 2002

Accepted: 30 January 2002

Published: 13 February 2002
Breast Cancer Res 2002, 4:62-64

(C) 2002 BioMed Central Ltd

(Print ISSN 1465-5411; Online ISSN 1465-542X)

\begin{abstract}
In breast cancer, interruption of estrogen receptor (ER)- $\alpha$ function is an effective therapeutic strategy. Despite the clinical benefit of interruption of ER- $\alpha$ function, the precise biological action of ER- $\alpha$ in breast tumors is not completely understood. Results of a recent study show that ER- $\alpha$ promotes growth of breast cancer cells by targeting expression of signaling components of the insulin-like growth factor system. Intriguingly, the authors of this study raise the possibility that unliganded ER- $\alpha$ itself may affect gene expression and breast cancer biology, and they suggest a potential mechanism for ER- $\alpha$ to stimulate proliferation in breast cancer.
\end{abstract}

Keywords: breast cancer, estrogen receptor, insulin-like growth factors

\section{The estrogen receptor and breast cancer}

It has long been known that ovarian production of the sex steroid hormone, estrogen, affects growth, differentiation, and function of the mammary gland. Estrogen mediates its effects by binding to its receptors, estrogen receptor (ER)- $\alpha$ and ER- $\beta$. Because ER- $\alpha$ was the first receptor subtype to be identified in the breast, most studies have focused on the biological role of ER- $\alpha$ in the mammary gland. It has recently been shown that ER- $\beta$ is also expressed in breast cancer, but its function remains elusive [1]. Classically, ER- $\alpha$ is thought to function as a ligand-activated transcription factor. By interacting with estrogenresponse elements contained in the promoter region of specific genes, modulation of gene expression ultimately results in the biological effects of estrogen. Extracellular signals can also stimulate ER- $\alpha$-mediated transcription in the absence of estrogen. In recent years, emerging evidence has revealed that a role for ER- $\alpha$ is to affect gene expression in the absence of direct DNA binding. For example, liganded ER- $\alpha$ can influence gene expression by associating with other transcription factors without binding directly to DNA. Despite the clear understanding of the genomic mechanism of estrogen action, it is also postulated that estradiol can exert nongenomic effects on cell biology by interacting with other proteins, including a putative membrane estrogen receptor, growth factor receptors, and intermediate cell signaling molecules [2-4].

Clinically, breast cancers have been classified as either ER- $\alpha$-positive or ER- $\alpha$-negative. While patients with ER- $\alpha$ positive tumors have a slightly better survival rate than patients with ER- $\alpha$-negative tumors, expression of ER- $\alpha$ is more useful as a predictive factor for response to endocrine therapy. Over half of patients with tumors positive for both ER- $\alpha$ and the progesterone receptor respond to therapy, such as tamoxifen, that is designed to interrupt the function of ER- $\alpha$ [5].

\section{Clues from in vitro studies: expression of ER- $\alpha$ in ER- $\alpha$-negative breast cancer cells}

Despite the clear clinical benefit for the interruption of ER- $\alpha$ function in breast cancer cells, the precise mechanism of ER- $\alpha$ action is still not completely understood. To clarify the role of estrogen and ER- $\alpha$ in growth responses, investi- 
gators have attempted to express ER- $\alpha$ in breast cancer cell lines to test the hypothesis that maintenance of ER- $\alpha$ expression in breast tumors would restore estrogen responsiveness and tumor sensitivity to endocrine therapy. In 1992, Jiang and Jordan expressed ER- $\alpha$ in the ER-negative breast cancer cell line MDA-MB-231 [6]. Paradoxically, they discovered that estradiol inhibited, rather than stimulated, cell proliferation. In spite of these findings, both the action of an estrogen-responsive reporter construct and the expression of an endogenous estrogen-responsive gene could be stimulated by estrogen. In the same year, Garcia et al. demonstrated that MDA-MB-231 cells transfected with ER- $\alpha$ had decreased metastatic potential in the presence of estradiol when injected into the tail vein of athymic, ovariectomized nude mice [7]. Subsequent studies that introduced ER- $\alpha$ into breast epithelial cell lines that do not express the receptor have shown similar inhibitory effects of estradiol on cell growth [8-10]. However, expression of ER- $\alpha$ in ER- $\alpha$-negative breast cancer cell lines does not appear to simulate ER- $\alpha$ function. Thus, the mechanism of ER- $\alpha$ function in breast cancer cells has not been elucidated by these studies.

Oesterreich and her colleagues report the creation of a MCF7 cell line that is unresponsive to estrogen [11]. The MCF7 parent cells are ER- $\alpha$-positive and proliferate in response to estradiol. After starving the cells of estrogen for nine months, the MCF7 cells no longer expressed ER$\alpha$ or proliferated in response to estradiol. Compared to other studies, Oesterreich et al. are the first authors to demonstrate that stable expression of ER- $\alpha$ in a hormonally unresponsive breast cancer cell line re-established estrogen control over proliferation. Why did the introduction of ER- $\alpha$ into ER-negative breast cancer cells in Oesterreich's study reconstitute estrogen-dependent growth, while previous studies have shown growth inhibition by estrogen? These conflicting results show that celldependent effects of estradiol do not depend solely on ER- $\alpha$ expression. The cellular pool of regulatory factors probably influence transcriptional activity of ER- $\alpha$, and determine the pattern of gene expression. The cells used in Oesterreich's study were initially derived from cells possessing an ER- $\alpha$-positive, hormonally responsive phenotype. In contrast, MDA-MB-231 cells are not ER-positive or hormonally responsive to estrogen. Even though the MCF7 cells used in the study did not express ER- $\alpha$, the cells must express essential endogenous coregulatory factors that are required for induction of genes involved in estradiol-induced proliferation. What are the genes regulated by estradiol in this system?

\section{The insulin-like growth factor signaling system is a target of ER- $\alpha$ action}

Intriguingly, Oesterreich et al. found that expression of ER- $\alpha$ was directly correlated with expression of the key components of the insulin-like growth factor (IGF) signal- ing system, including the type 1 IGF-receptor and insulinreceptor substrate-1 [11]. Considerable crosstalk has already been documented between the signaling pathways of estrogen and the IGFs [12]. A potent mitogen, IGF-I, in breast cancer cells can act synergistically with estrogen to stimulate ER- $\alpha$-positive breast cancer cell proliferation [13]. It has also been suggested that signaling components of the IGF-I system are regulated by estrogen [14]. Here, loss of ER- $\alpha$ was associated with decreased expression of proteins in the IGF-I signaling system, diminished IGF signal transduction, and no growth response to estrogen or IGF-I. Re-expression of ER- $\alpha$ in these cells restored expression of molecules critical to IGF signaling as well as the proliferative response to estrogen. These results show that ER- $\alpha$ is a critical regulator of IGF-Iinduced proliferation. In the absence of ER- $\alpha$, key components of the IGF signaling pathway are lost. Thus, one way that ER- $\alpha$ can stimulate breast cancer growth is by maintaining and regulating responsiveness to the IGFs.

Even though re-introduction of ER- $\alpha$ into the cells restored the hormone-responsive proliferative phenotype, the cells did not completely reconstitute the ER- $\alpha$ phenotype. For example, estrogen treatment failed to induce expression of a key endogenous estrogen-responsive gene, the progesterone receptor gene. Since the cells were derived from MCF7 cells that have been shown to induce progesterone receptor expression following estrogen treatment, one would hypothesize that the cells would express the proper combination of coregulatory factors required for induction of the progesterone receptor gene. Thus, expression of ER- $\alpha$ in the ER- $\alpha$-negative breast cancer cell line used by Oesterreich et al. [11] was still not able to restore all hormone-dependent features of estrogen.

This study also highlights a paradox concerning the biological role of ER- $\alpha$ in breast tissue. Cells expressing ER- $\alpha$ require the receptor for growth and can be growthretarded by inhibition of the receptor. However, cells that originally expressed ER- $\alpha$ in Oesterreich's study [11], and were subsequently selected to lose its expression, appeared to have a growth advantage. It is possible that other growth regulatory pathways were upregulated while cells were selected for the loss of ER- $\alpha$. For example, in human breast cancer specimens, ER- $\alpha$ expression correlates inversely with epidermal growth factor receptor (EGFR). A study using MCF7 cells overexpressing EGFR demonstrated that cell growth rate could be augmented by omitting estrogen from the growth media, indicating that ER- $\alpha$ can be a growth inhibitor under some circumstances [15]. Recently, hyperactivation of mitogenactivated protein kinase was shown to downregulate ER- $\alpha$ expression in breast cancer cells that were overexpressing EGFR [16]. Considering this, perhaps other growth stimulatory pathways, such as the epidermal growth factor system, became upregulated in the ER- $\alpha$-negative cells 
used in Oesterreich's study [11] and provided an alternative growth stimulus for estrogen and the IGF-I system.

\section{Does ER- $\alpha$ affect gene expression in the absence of estrogen?}

Since ER- $\alpha$-positive tumors generally exhibit a less aggressive phenotype than ER- $\alpha$-negative tumors, ER- $\alpha$ is considered to be a differentiation marker in breast cancer. While Oesterreich et al. showed that re-expression of the receptor restored estrogen- and IGF-mediated growth, their data also suggested that re-expression of ER- $\alpha$ tended to suppress proliferation compared to cells that were selected to lose ER- $\alpha$ expression [11]. The observation that unliganded ER- $\alpha$ affected gene expression and biological function shows that ER- $\alpha$ itself can influence breast cancer cells, even in the absence of estrogen. Although it is possible that low concentrations of estrogen in the media were responsible for the restored gene expression, it seems unlikely because the cells were maintained in serum stripped of endogenous steroids. A previous study has shown that ligand binding to ER- $\alpha$ is not required for receptor dimerization or binding of the receptor to its response elements [17]. Recent findings have also suggested that ER- $\beta$ and ER- $\alpha$ have ligand-independent effects on motility and migration when expressed in MDA-MB-231 breast cancer cells [18].

Although the biological effects of estrogens on the breast are well known, the specific targets of ER- $\alpha$ to promote growth are largely unknown. Oesterreich et al. have provided two pieces of evidence suggesting how ER- $\alpha$ stimulates proliferation in breast cancer cells [11]. First, the components of the IGF-I signaling system are targets of ER- $\alpha$ action. Cells that lose ER- $\alpha$ expression also lose the IGF signaling pathway. These results provide the clearest demonstration of the crosstalk between estrogen and the IGF-I pathway. Second, ligand-independent actions of ER- $\alpha$ on cell biology are suggested by the finding that expression of the type 1 IGF-receptor and insulin-receptor substrate- 1 were restored when ER- $\alpha$ expression was restored. It also appears that cells which have lost ER- $\alpha$ expression grow faster than their ER- $\alpha$-positive parent cells. One possible explanation for this finding is that unliganded ER- $\alpha$ may affect expression of genes involved in proliferation or differentiation. Oesterreich et al. have clearly shown that expression of ER- $\alpha$ by itself influences expression of IGF signaling components, and that activation of receptor further stimulates gene expression [11]. Are there an opposing set of growth inhibitory genes that are repressed by activation of ER- $\alpha$ ? Indeed, the idea that estrogen functions to cancel growth inhibitory signals has also been suggested by another recent study [19].

The results of Oesterreich et al. [11] challenge the dogma that ER- $\alpha$ only depends on ligand to affect gene expression, and introduce the possibility that unliganded ER- $\alpha$ itself may have important biological effects. Clinically, this suggests that inhibition of ER- $\alpha$ function could have substantially different biological effects than loss of ER- $\alpha$ expression.

\section{References}

1. Roger P, Sahla ME, Makela S, Gustafsson JA, Baldet P, Rochefort $\mathrm{H}$ : Decreased expression of estrogen receptor beta protein in proliferative preinvasive mammary tumors. Cancer Res 2001 , 61:2537-2541.

2. Kahlert S, Nuedling S, van Eickels M, Vetter H, Meyers R, Grohe C: Estrogen receptor-alpha rapidly activates the IGF-I receptor pathway. J Biol Chem 2000, 275:18447-18453.

3. Razandi M, Pedram A, Levin ER: Plasma membrane estrogen receptors signal to antiapoptosis in breast cancer. $\mathrm{Mol}$ Endocrinol 2000, 14:1434-1447.

4. Peitras RJ, Szego CM: Specific binding sites for oestrogen at the outer surfaces of isolated endometrial cells. Nature 1977, 265:69-72

5. Buzdar AU: Endocrine therapy in the treatment of metastatic breast cancer. Semin Oncol 2001, 28:291-304.

6. Jiang S-Y, Jordan VC: Growth regulation of estrogen receptornegative breast cancer cells transfected with complementary DNAs for estrogen receptor. J Natl Cancer Inst 1992, 84:580591.

7. Garcia M, Derocq D, Freiss G, Rochefort H: Activation of estrogen receptor transfected into a receptor-negative breast cancer cell line decreases the metastatic potential and invasive potential of the cells. Proc Natl Acad Sci USA 1992, 89: 11538-11542.

8. Zajchowski DA, Sager R, Webster L: Estrogen inhibits growth of estrogen receptor-negative, but not estrogen receptor-positive, human mammary epithelial cells expressing a recombinant receptor. Cancer Res 1993, 53:5004-5011.

9. Lundholt BK, Madsen MW, Lykkesfeldt AE, Petersen OW, Briand $\mathrm{P}$ : Characterization of a nontumorigenic human breast epithelial cell line stably transfected with the human estrogen receptor (ER) cDNA. Mo/ Cell Endocrinol 1996, 119:47-59.

10. Lazennec G, Katzenellenbogen BS: Expression of human estrogen receptor using an efficient adenoviral gene delivery system is able to restore hormone-dependent features to estrogen receptor-negative breast cancer cells. $\mathrm{Mol} \mathrm{Cell}$ Endocrinol 1999, 149:93-105.

11. Oesterreich $S$, Zhang $P$, Guler RL, Sun X, Curran EM, Welshons WV, Osborne CK, Lee AV: Re-expression of estrogen receptor- $\alpha$ in estrogen receptor $\alpha$-negative MCF-7 cells restores both estrogen and insulin-like growth factor-mediated signaling and growth. Cancer Res 2001, 61:5771-5777.

12. Yee $D$, Lee AV: Crosstalk between the insulin-like growth factors and estrogens in breast cancer. J Mammary Gland Biol Neoplasia 2000, 5:107-115.

13. Stewart AJ, Westley BR, May FE: Modulation of the proliferative response of breast cancer cells to growth factors by oestrogen. Br J Cancer 1992, 66:640-648.

14. Lee AV, Jackson JG, Gooch JL, Hilsenbeck SG, Coronado-Heinsohn E, Osborne CK, Yee D: Enhancement of insulin-like growth factor signaling in human breast cancer: estrogen regulation of insulin receptor substrate-1 expression in vitro and in vivo. Mol Endocrinol 1999, 13:787-796.

15. Miller DL, El-Ashry D, Cheville AL, Liu Y, McLeskey SW, Kern FG: Emergence of MCF-7 cells overexpressing a transfected epidermal growth factor receptor (EGFR) under estrogen-depleted conditions: evidence for a role of EGFR in breast cancer growth and progression. Cell Growth Differ 1994, 5:1263-1274.

16. Oh AS, Lorant LA, Holloway JN, Miller DL, Kern FG, El-Ashry D: Hyperactivation of MAPK induces loss of ER-alpha expression in breast cancer cells. Mol Endocrinol 2001, 15:1344-1359.

17. Zhuang Y, Katzenellenbogen BS, Shapiro DJ: Estrogen receptor mutants which do not bind 17beta-estradiol dimerize and bind to estrogen response element in vivo. Mol Endocrinol 1995, 9:457-466.

18. Lazennec G, Bresson D, Lucas A, Chauveau C, Vignon F: ERbeta inhibits proliferation and invasion of breast cancer cells. Endocrinology 2001, 142:4120-4130.

19. Soto AM, Sonnenshcein C: The two faces of Janus: sex steroids as mediators of both cell proliferation and cell death. J Natl Cancer Inst 2001, 93:1673-1675. 